\title{
The impact of fiscal policies on corruption: A panel analysis
}

\begin{tabular}{|c|c|}
\hline \multicolumn{2}{|c|}{$\begin{array}{l}\text { Authors: } \\
\text { Monica V. Achim } 1 \text { (1) } \\
\text { Sorin N. Borlea } \\
\text { Andrei M. Anghelina }\end{array}$} \\
\hline \multicolumn{2}{|c|}{$\begin{array}{l}\text { Affiliations: } \\
{ }^{1} \text { Department of Finance, } \\
\text { Faculty of Economics and } \\
\text { Business Administration, } \\
\text { Babes-Bolyai University, } \\
\text { Romania }\end{array}$} \\
\hline \multicolumn{2}{|c|}{$\begin{array}{l}{ }^{2} \text { Department of Economics, } \\
\text { Faculty of Economics, } \\
\text { Informatics and Engineering, } \\
\text { Vasile Goldiș Western } \\
\text { University of Arad, Romania }\end{array}$} \\
\hline \multicolumn{2}{|c|}{$\begin{array}{l}\text { Corresponding author: } \\
\text { Monica Achim, } \\
\text { monica.achim@econ. } \\
\text { ubbcluj.ro }\end{array}$} \\
\hline $\begin{array}{l}\text { Dates: } \\
\text { Received: } 06 \mathrm{~J} \\
\text { Accepted: } 19 \\
\text { Published: } 04\end{array}$ & $\begin{array}{l}\text { une } 2017 \\
\text { Oct. } 2017 \\
\text { Apr. } 2018\end{array}$ \\
\hline \multicolumn{2}{|c|}{$\begin{array}{l}\text { How to cite this article: } \\
\text { Achim, M.V., Borlea, S.N. \& } \\
\text { Anghelina, A.M., 2018, 'The } \\
\text { impact of fiscal policies on } \\
\text { corruption: A panel analysis', } \\
\text { South African Journal of } \\
\text { Economic and Management } \\
\text { Sciences 21(1), a1970. } \\
\text { https://doi.org/10.4102/ } \\
\text { sajems.v21i1.1970 }\end{array}$} \\
\hline \multicolumn{2}{|c|}{$\begin{array}{l}\text { Copyright: } \\
\text { (c) 2018. The Authors. } \\
\text { Licensee: AOSIS. This work } \\
\text { is licensed under the } \\
\text { Creative Commons } \\
\text { Attribution License. }\end{array}$} \\
\hline \multicolumn{2}{|l|}{ Read online: } \\
\hline 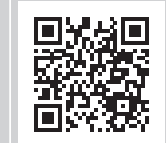 & $\begin{array}{l}\text { Scan this QR } \\
\text { code with your } \\
\text { smart phone or } \\
\text { mobile device } \\
\text { to read online. }\end{array}$ \\
\hline
\end{tabular}

Authors:

Affiliations:

Department of Finance, Business Administration, Babes-Bolyai University,

${ }^{2}$ Department of Economics, Faculty of Economics, formatics and Engineering, Vasile Goldiș Western

Corresponding author:

Monica Achim,

monica.achim@econ.

Dates:

Received: 06 June 2017 Accepted: 19 Oct. 2017

How to cite this article: Achim, M.V., Borlea, S.N. \& Anghelina, A.M., 2018, 'The South African Journal of Economic and Management https://doi.org/10.4102/

Copyright: Licensee: AOSIS. This work is licensed under the Creative Commons Attribution License. mobile device to read online.

\begin{abstract}
This article seeks to complement the previous literature and clarify whether fiscal policy plays a role in the level of corruption of a country. The present work investigates whether the increase in fiscal pressure leads to a higher level of corruption and whether the results differ from developed to developing countries. This article examines a large sample consisting of over 185 countries, during the period 2005-2014. The technique employed was short panel data. Five statistical models were used such as the pooled OLS, pooled FGLS, within model, between model and random-effects GLS model. Our main contribution consists in finding differentiated results of the influence of fiscal policy on the level of corruption among developed and developing countries. For developed countries, we found that, with high-quality institutions, low fiscal pressure leads to a lower level of corruption, which is in line with expectations. Conversely, in developing countries, with low-level institutional quality, low fiscal pressure increases corruption, because of low governance efficiency under which people may easily circumvent the law. Our findings suggest that governments and policy-makers need to acknowledge that the anti-corruption fight requires not only the right fiscal policies but also the right way of implementing these policies, recognising the role of quality institutions, which need to prevail in any country.
\end{abstract}

\section{Introduction}

Corruption is a phenomenon that has originated since ancient times. It is considered the worst and most widespread form of behaviour, perverting public affairs (Conseil de l' Europe 1996:78). According to Transparency International (2015), 'Corruption is the abuse of entrusted power for private gain. It can be classified as grand, petty and political, depending on the amounts of money lost and the sector where it occurs. A short definition is provided by the World Bank (1997) according to which corruption is 'the abuse of public office for private gain'. Corruption undermines democratic governance and the rule of law and negatively affects economic development, being an impediment to increasing investment and growth (Lambsdorff 2003; Mauro 1995).

Fiscal policy is often linked with corruption, in which the bribing of officials is done by entrepreneurs in order to obtain private gains, such as avoiding taxation and regulations, or winning public contracts (Fjeldstad 1996, 2003; Kaufman 2010). The starting point of this study consists in finding few, inconclusive results in the literature regarding the influence of fiscal pressure on the level of corruption (Dreher \& Schneider 2010; Dreher \& Siemers 2009; McGee 2012). Thus, the objective of the present research consists in filling this gap, by analysing the influence of fiscal pressure on the level of corruption, using two main control variables, such as wealth and institutional quality. A panel analysis was conducted on a large sample of 185 countries over the period 2005-2014. Our main contribution to previous work consists in finding differentiated results when the influence of fiscal burden on the level of corruption is controlled by income and institutional quality. Thus, in developed countries with high-quality institutions, we found that lower fiscal pressure leads to a lower level of corruption, supporting expectations. On the contrary, we found that in developing countries with low-level institutional quality, low fiscal pressure increases corruption, because of low governance efficiency under which people may easily circumvent the law. Our findings suggest that certain fiscal policies may work in some countries, but not in others. Thus, governments and policy-makers need to acknowledge that the anti-corruption fight requires not only the right fiscal policies but also the right way of implementing these policies, whilst recognising the role of quality institutions prevailing in any country.

The rest of this article is organised as follows: In the 'Literature review' section, the theoretical considerations are laid out, according to which the main working hypotheses are set. In the 'Data and methodology' section, the methodology and data sources are provided. In order to substantiate 
the econometric model of corruption, several control variables already validated by the literature were used. The 'Results' section highlights the results and discussions of the main empirical findings. The article ends with the main conclusions of the study, including some limitations which could be the basis for future work in this area of research.

\section{Literature review}

The problem of corruption and its explanatory factors are widely debated in the literature. It is important for policymakers to know the causes of corruption, in order to open up the proper channels for fighting against it. The literature on corruption has typically focused on the administration of bribes or obtaining private gain by abusing public officials. This private gain is made by entrepreneurs in avoiding taxation and regulations, and winning public contracts. Therefore, it is possible to derive some direct connections between various aspects of fiscal policy and corruption.

To our knowledge, relatively few strands in the literature (Dreher \& Schneider 2010; Dreher \& Siemers 2005, 2009; McGee 2008, 2012) have investigated the influence of fiscal pressure on levels of corruption, and the results are inconsistent. For instance, Dreher and Siemers (2005) analysed the relationship between corruption and capital account restrictions, using a panel data of 112 countries over the period 1984-1999. They found that heavy capital account restrictions involved higher corruption in the earlier years up to 1993, but reduced corruption in later years. Later, Dreher and Schneider (2010) analysed a crosssection data of 120 countries and a panel data of 70 countries during 1994-2002. They also obtained results documenting that corruption is more severe in countries with smaller fiscal burdens, contradicting expectations. Analysing the perception on tax evasion and corruption in Denmark, McGee (2008) revealed that Danish people view tax evasion very negatively, even though their tax rate is one of the highest in the world; hence, the low-level of corruption in Denmark could be explained. Similarly, McGee (2012) explained the situation in Armenia, where, although the tax burden is substantially less than most other countries, people are not so strongly opposed to tax evasion, thus leading to a high level of corruption. Another paradox can be found in China. Various authors (Huang 2016; Jiang \& Nie 2014) empirically reported on the Chinese miracle of continuing high growth in the gross domestic product (GDP), with the prevalence of government corruption. Kumar (2011) noted the anomaly of emerging China, which is characterised by low economic freedom, high corruption and high growth.

Emerging from these inconclusive findings, questions may be asked concerning the higher fiscal burden will create opportunities for bribing officials, in order to avoid taxes or win public contracts. Intuitively, bribes are paid to avoid paying taxes or following regulations; therefore, it can be assumed that a higher fiscal burden could increase corruption. Thus, the following hypothesis may be posed:
Hypothesis 1: Increasing fiscal pressure is associated with a higher level of corruption.

An important strand of research (Dreher \& Schneider 2010; Graeff \& Mehlkop 2003; Virta 2007) reveals differentiated behaviour among various economic variables related to corruption, depending on the stage of development. Graeff and Mehlkop (2003) found that some aspects of economic freedom deter corruption, whilst others do not. They discovered a strong relationship between economic freedom and corruption, and that this relationship differs between rich and poor countries. Dreher and Schneider (2010) demonstrated that the relationship between corruption and the shadow economy differs between high- and low-income countries. They found that the shadow economy reduces corruption in high-income countries but increases corruption in low-income countries. Also, some authors, such as Virta (2007), investigated the relationship between corruption and the shadow economy by regions. Among countries in tropical regions, a negative relationship was found between corruption and the shadow economy, because in such regions, public officials are commonly paid for remaining official, and thus the shadow economy decreases if corruption increases. According to these findings, we intend to test the following research question:

Research question 1: How do the results of testing Hypothesis 1 differ between developed and developing countries?

\section{Data and methodology}

\section{Variables and data sources The dependent variable: Corruption}

To measure corruption, the Corruption Perceptions Index (CPI) provided by Transparency International was used. This index measured the perceived levels of public sector corruption in 175 countries. The scores range from 0 (highly corrupt) to 100 (very clean). The ranking of countries from 1 (lowest level of corruption) to 175 (highest level of corruption) was done during the period 2005-2014.

\section{The independent variable: Fiscal pressure or fiscal burden}

According to Schneider, Buehn and Montenegro (2010), the measurement of fiscal burden is not easy to define, because the tax and social security systems are vastly different among countries. A measure of fiscal burden is fiscal freedom, which is composed of three quantitative factors (j), namely: (1) the top marginal tax rate on individual income; (2) the top marginal tax rate on corporate income; and (3) the total tax burden as percentage of GDP (Heritage Foundation 2017). A fiscal freedom score is therefore calculated as follows:

Fiscal freedom ${ }_{\mathrm{ij}}=100-\alpha\left(\text { Factor }_{\mathrm{ij}}\right)^{2}$

[Eqn 1]

where:

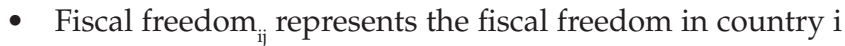
for each factor $j$. 
- Factor ${ }_{\mathrm{ij}}$ represents the value (based on a scale of 0-100) in country i for factor $j$.

- $\quad \alpha$ is a coefficient set equal to 0.03 .

The higher the fiscal burden, the lower the fiscal freedom. This survey deals with the fiscal freedom variable (FIF), as a proxy variable for tax burden. It includes both the direct tax burden in terms of the top tax rates on individual and corporate incomes, and the overall amount of tax revenue as percentage of GDP. The fiscal freedom index ranges from 0 to 100 , where 0 is the least fiscal freedom and 100 is the maximum degree of fiscal freedom. The FIF has been used by various authors in their research (Dreher \& Schneider 2010; Torgler \& Schneider 2009) in order to express the level of fiscal burden of a country.

\section{Selected control variables}

The present study investigates the influence of fiscal pressure on the level of corruption. A number of other important factors, such as income and institutional quality of a country had to be controlled, and are discussed as follows.

\section{Income}

Various studies (De Rosa, Gooroochurn \& Gorg 2010; Husted 1999; Paldam 2001, 2002; Treisman 2000) reported that high-income countries face a low-level of corruption. Husted (1999) argued that 'since the level of development is related to the overall level of resource munificence, one would expect that corruption would be more common in the less developed economies'. Treisman (2000) and Paldam (2001, 2002) found that corruption is a povertydriven disease which vanishes when the country becomes richer. Goel and Ram (2013) substantiated these findings and documented that transition economies have more corruption than developed countries. Gundlach and Paldam (2009) pointed out that the cross-country pattern of corruption can be fully explained by the cross-country pattern of income, and De Rosa et al. (2010) found a strong correlation of 0.81 between GDP and the level of corruption. However, Huang (2016) found no significant causality between corruption and economic growth among most Asia-Pacific countries and concluded that, for these countries, the anti-corruption policies used by policymakers to promote a country's economic development may not be effective.

Based on the empirical findings stated above, the following hypothesis and research questions were formulated:

Hypothesis 2: Increasing income of a country is associated with a lower level of corruption.

Research question 2: How do the results of testing Hypothesis 2 differ between developed and developing countries?

Gross domestic product is a proxy for the level of development and prosperity of a region. Next, the per capita GDP is used as a proxy for the income of a country.

\section{Institutional quality}

Various studies have highlighted the importance of providing a high level of confidence in governance institutions, in order to ensure the proper functioning of the state (Fritzen, Serritzlew \& Svendsen 2014; Kirchler 2007; Park \& Blenkinsopp 2011; Torgler \& Schneider 2009). Corruption and trust are two important determinants of the quality of public sectors (Fritzen et al. 2014). Better institutional quality encourages people to have trust in the state, and to be less interested in 'playing tricks'.

Government has strong discretionary powers over the allocation of resources, and bribes may be paid to avoid paying taxes or following regulations (Torgler \& Schneider 2009); hence, trusting societies demonstrate less corruption.

Trust in government or public services reflects citizens' subjective judgements, based on their experience, in which they judge the government as being competent, reliable and honest, whilst also meeting their needs (Park \& Blenkinsopp 2011). Low institutional quality determines a low trust in governance, which fails to determine ways of circumventing the law (Kirchler 2007). One of these consists in bribing officials to avoid taxes, and thus increases corruption. In this respect, Dreher, Kotsogiannis and McCorriston (2009) empirically found that an improvement in institutional quality reduced the shadow economy and affected the corruption market in 18 OECD countries.

Therefore, the following secondary hypothesis can be stated:

Hypothesis 3: A higher level of institutional quality reduces the level of corruption.

Research question 3: How do the results of testing Hypothesis 3 differ between developed and developing countries?

Institutional quality is measured using the good government effectiveness (GE), as provided through the Worldwide Governance Indicators by the World Bank (2016b). According to various researchers (Carden \& Verdon 2010; Graeff \& Mehlkop 2003; Kumar 2011), corruption can be analysed multi-dimensionally. Following these findings, we intend to analyse the variation in corruption according to the simultaneous influences of fiscal freedom, institutional quality and richness of the country. Therefore, the following hypothesis and research questions were proposed:

Hypothesis 4: Higher fiscal pressure, lower institutional quality and lower degree of richness of a country are associated with a higher level of corruption.

Research question 4: How do the results of testing Hypothesis 4 differ between developed and developing countries?

The variables used and data sources for these variables are shown in Table 1.

The current research was developed further in order to classify the countries, by level of development, in developed and developing countries. This classification is based on the data provided by the World Bank report on 'Country and 
TABLE 1: Variables and data sources.

\begin{tabular}{|c|c|c|c|c|}
\hline Variable name & Estimator & Type of variable & Description & Source \\
\hline Corruption & $\begin{array}{l}\text { Corruption } \\
\text { Perceptions Index }\end{array}$ & $\begin{array}{l}\text { Dependent } \\
\text { variable }\end{array}$ & $\begin{array}{l}\text { We deal with the country rankings ranging from } 1 \text { (lowest level } \\
\text { of corruption) to } 185 \text { (highest level of corruption) }\end{array}$ & $\begin{array}{l}\text { Corruption Perceptions Index (Transparency } \\
\text { International, 2015) }\end{array}$ \\
\hline Fiscal burden & Fiscal freedom & $\begin{array}{l}\text { Independent } \\
\text { variable }\end{array}$ & $\begin{array}{l}\text { It ranges from } 0 \text { to } 100 \text {, where } 0 \text { is the least fiscal freedom and } \\
100 \text { is the maximum degree of fiscal freedom. A higher fiscal } \\
\text { burden implies a lower degree of fiscal freedom }\end{array}$ & $\begin{array}{l}\text { Index of economic freedom } \\
\text { (Heritage Foundation, 2017) }\end{array}$ \\
\hline Income & $\begin{array}{l}\text { Gross domestic } \\
\text { product per capita }\end{array}$ & $\begin{array}{l}\text { Independent } \\
\text { variable }\end{array}$ & $\begin{array}{l}\text { GDP per capita (current US\$). GDP per capita is gross domestic } \\
\text { product divided by mid-year population }\end{array}$ & Indicators (World Bank 2016a) \\
\hline $\begin{array}{l}\text { Institutional } \\
\text { quality }\end{array}$ & $\begin{array}{l}\text { Good government } \\
\text { effectiveness }\end{array}$ & $\begin{array}{l}\text { Independent } \\
\text { variable }\end{array}$ & $\begin{array}{l}\text { It reflects the perceptions of the quality of public services, } \\
\text { their ability to produce and implement good policies and } \\
\text { deliver public goods. It ranges from }-2.5 \text { (weak) to } 2.5 \text { (strong) } \\
\text { in governance performance }\end{array}$ & $\begin{array}{l}\text { Worldwide Governance Indicators (World Bank } \\
\text { 2016b) }\end{array}$ \\
\hline
\end{tabular}

GDP, gross domestic product.

Lending Groups' 2015 (World Bank 2015), where countries are classified by high-income, upper-middle-income, lower middle-income and low-income. The classification of countries is based on the average value of Gross National Income per capita, as follows: high-income (Gross National Income per capita of $\$ 12746$ or more); upper-middle-income economies (Gross National Income per capita of more than $\$ 4126$ but less than $\$ 12$ 736); middle-income economies (Gross National Income per capita of more than $\$ 1045$ but less than \$4125); and low-income economies (below Gross National Income per capita of less than \$1045). Therefore, the World Bank (2015) classified the low- and middle-income economies as 'developing' economies and the high-income countries as 'developed' economies. The present study sample consists of 185 countries (49 developed and 136 developing countries), for which all the required data are available.

In order to show the influence of the considered variables on corruption, the following baseline equation model was proposed, according to Hypothesis 4:

$\mathrm{CPI}_{\mathrm{i}}=\beta_{0}+\beta_{1} \mathrm{FIF}_{\mathrm{i}}+\beta_{2} \mathrm{GDP}_{\mathrm{i}}+\beta_{3} \mathrm{GE}_{\mathrm{i}}+\varepsilon_{\mathrm{i}}$

- $\mathrm{CPI}_{\mathrm{i}}$ reflects the level of corruption of a country $\mathrm{i}$.

- FIF $_{\mathrm{i}}$ is the fiscal freedom variable (a negative sign is expected).

- $\mathrm{GDP}_{\mathrm{i}}$ is the wealth of a country, estimated by GDP per capita (a negative sign is expected).

- $\mathrm{GE}_{\mathrm{i}}$ denotes the institutional quality reflected by good government effectiveness (a negative sign is expected).

- $\boldsymbol{\varepsilon}_{\mathrm{i}}$ reveals the error term.

\section{Methods}

The data organised in a short time panel are repeated in yearly measurements over the period 2005-2014 for 185 countries, for which all required data are available. All 185 countries have exactly 9 years of data and the panel is balanced. The dependent variable (CPI) and regressors (FIF, GDP and GE) vary over both time and countries. All the variables are time-varying regressors. Variation over time is called within variation, and variation across countries is called between variation.

This clarification is very important, because the used estimators differ in relation to within and between variations.
For this purpose, five statistical models were used: the 'pooled Ordinary Least Square' ('pooled OLS') model denoted as (1), the 'population-averaged' or 'pooled Feasible Generalised Least Squares' (pooled FGLS) model denoted as (2), the 'within' model or 'fixed effects' ('FE') denoted as (3), the 'between' model ('BE') denoted as (4) and 'randomeffects GLS' model ('RE') denoted as (5). The five models used allowed us to capture the components of the variation of variables used in hypothesis testing. A natural starting point is the pooled OLS regression with cluster-robust standard errors. The estimator OLS is based on the total variance of the variables, not distinguishing between 'within' and 'between' variation. For any error correlation, given a model for error correlation, a more-efficient FGLS estimation is possible. When 'within' variation is significant, the 'within' model is used in order to show how the testing hypothesis is affected. The 'between' model uses cross-section variation in the data and is based on average values of variables. It is interesting to know if the hypothesis is valid when the average values for each country are used. The 'RE' model uses both between and within variation in the data. This model assumes that the time-invariant component of the error (caused by individual-specific-effects) and the timevarying component of error are independent and identically distributed.

\section{Results and discussions}

Firstly, Hypothesis 1 examined the relationship between fiscal pressure and corruption. Theoretically, there is a reason to believe that increasing fiscal pressure is associated with a higher level of corruption. The results of testing the hypothesis are shown in Tables $2-4$. The results are based on linear regressions including the dependent variable, CPI and one explanatory variable, FIF, at the time.

Tables 2-4 show that fiscal pressure significantly affects the level of corruption, apart from model (3), having analysed all countries in the sample. The results of model (3) show that the impact of fiscal pressure on the level of corruption is statistically insignificant. Perhaps, it would be interesting to see the result of model (3) for a long panel. The coefficients of FIF determinant in models (1), (2), (4) and (5) are the most significant at $5 \%$ level of significance. However, the sign of FIF coefficient contradicts Hypothesis 1. For all countries, higher fiscal freedom (which involves a lower fiscal burden) implies a higher level of corruption, which does not support 
our Hypothesis 1. Rather, we got the opposite results, namely, that lower fiscal pressure leads to a higher level of corruption.

Research question 1 investigates how the results of testing Hypothesis 1 differ between developed and developing countries. The results are listed in Tables $2-4$. It is found that, for developed countries, the results of models (1), (2) and (4) are also significant at $1 \%$ level of significance. The results of models (3) and (5) for developed countries are inconclusive (the influence is not statistically significant). Models (1), (2) and (4) also show that fiscal pressure is a significant determinant of corruption but not in the expected way. The coefficient of determinant FIF is positive; therefore, higher fiscal freedom (meaning lower fiscal pressure) implies a higher level of corruption. For developing countries, the hypothesis results are significant only in the case of model (2). This model takes into account the high correlation errors, thus leading to inconclusive results. For the other models, the impact of fiscal pressure is not significant and the sign of the FIF determinant contradicts the hypothesis.

Concluding, our results do not support Hypothesis 1. This means that in countries across the world, high fiscal pressure is not a real reason for corruption. Moreover, we even found opposed evidence that lower fiscal pressure (reflecting higher fiscal freedom) may be a reason for corruption, and these results are statistically significant for all the countries sampled. When the countries were analysed by stages of development, the same results were generally maintained across the developed countries, with $1 \%$ level of significance in three of the five models: models (1), (2) and (4). For developing countries, the results have some consistency only for one model (2). Our findings contradict the expectation that a higher fiscal burden induces a higher level of corruption. However, these results are generally supported by those of Dreher and Siemers (2005, 2009), Dreher and Schneider (2010) and McGee (2008, 2012), who also found empirical evidence in this regard.

Secondly, Hypothesis 2 investigated the influence of income on the level of corruption. Tables 5-7 show the test results for all countries and separately classifies them by stages of development.

It was found that Hypothesis 2 is validated over the entire sample, except in model (3). Although, the GDP variable coefficient is significantly different from zero, the sign is not the expected one. For developed countries, the hypothesis is not accepted in the case of models (3) and (5) with doubts

TABLE 2: Variation of Corruption Perceptions Index depends on fiscal freedom variable, by stage of development: All.

\begin{tabular}{|c|c|c|c|c|c|c|c|c|c|c|c|}
\hline \multirow[t]{2}{*}{ Sample } & \multirow[t]{2}{*}{ Determinant } & \multicolumn{2}{|c|}{$\begin{array}{l}\text { Pooled OLS } \\
\text { estimator }^{\mathrm{a}}\end{array}$} & \multicolumn{2}{|c|}{$\begin{array}{l}\text { Pooled FGLS } \\
\text { estimator }^{\mathrm{b}}\end{array}$} & \multicolumn{2}{|c|}{$\begin{array}{l}\text { Within or FE } \\
\text { estimator }^{\mathrm{c}}\end{array}$} & \multicolumn{2}{|c|}{$\begin{array}{c}\text { Between or BE } \\
\text { estimator }^{\mathrm{d}}\end{array}$} & \multicolumn{2}{|c|}{$\begin{array}{c}\text { Random-effects or RE } \\
\text { estimator }^{\mathrm{e}}\end{array}$} \\
\hline & & coef. & t stat. & coef. & t stat. & coef. & t stat. & coef. & t stat. & coef. & t stat. \\
\hline All & FIF & 0.9538409 & $(3.14 * * *)$ & 0.2480613 & $(2.10 * *)$ & 0.2443562 & (1.48) & 0.8930844 & $(3.08 * * *)$ & 0.2959208 & $\left(1.90^{* *}\right)$ \\
\hline
\end{tabular}

FIF, fiscal freedom variable; coef., coefficients., $t$ stat., $t$ statistics; OLS, Ordinary Least Square; FGLS, Feasible Generalised Least Squares; FE, fixed effects; BE, between model; RE, random-effects. a, $R^{2}=0.14 \mathrm{~N}=420 \mathrm{~F}$-test $($ Prob $>\mathrm{F})=0.00 \mathrm{Std}$. Err. $=0.1653402 ;{ }^{b}, N=420 \mathrm{Std}$. Err. $=0.2263603$ Correlation $=\operatorname{ar}(1) ;{ }^{c}, N=420 R^{2}:($ wit $=0.002$ bet. $=0.143$ ov. $=0.145)$ Std. Err. $=0.2466242$ sigma_u $=$ 32.40 sigma_e $=5.58 ;{ }^{d}, N=420 R^{2}$ : (wit. $=0.002$ bet. $=0.143$ ov. $=0.145$ ) Std. Err. $=0.2628101 ;{ }^{\mathrm{e}}, N=420 R^{2}$ : (wit. $=0.002$ bet. $=0.143$ ov. $\left.=0.145\right)$ Std. Err. $=0.20707$ sigma_u $=29.78$ sigma_e $=5.58$. $*$, Denotes significant at $10 \%$ level, **, significant at $5 \%$ level, ***, significant at $1 \%$ level.

TABLE 3: Variation of Corruption Perceptions Index depends on fiscal freedom variable, by stage of development: Developed.

\begin{tabular}{|c|c|c|c|c|c|c|c|c|c|c|c|}
\hline \multirow[t]{2}{*}{ Sample } & \multirow[t]{2}{*}{ Determinant } & \multicolumn{2}{|c|}{$\begin{array}{l}\text { Pooled OLS } \\
\text { estimator }\end{array}$} & \multicolumn{2}{|c|}{$\begin{array}{l}\text { Pooled FGLS } \\
\text { estimator }\end{array}$} & \multicolumn{2}{|c|}{$\begin{array}{l}\text { Within or FE } \\
\text { estimator }\end{array}$} & \multicolumn{2}{|c|}{$\begin{array}{l}\text { Between or BE } \\
\text { estimator }{ }^{\mathrm{d}}\end{array}$} & \multicolumn{2}{|c|}{$\begin{array}{c}\text { Random-effects or RE } \\
\text { estimator }\end{array}$} \\
\hline & & coef. & t stat. & coef. & t stat. & coef. & t stat. & coef. & t stat. & coef. & t stat. \\
\hline Developed & FIF & 0.7450314 & $(4.51 * * *)$ & 0.6958028 & $(3.07 * * *)$ & -0.0776856 & $(-0.31)$ & 0.7266491 & $(2.76 * * *)$ & 0.0327392 & $(0.16)$ \\
\hline
\end{tabular}

TABLE 4: Variation of Corruption Perceptions Index depends on Fiscal freedom variable, by stage of development: Developing.

\begin{tabular}{|c|c|c|c|c|c|c|c|c|c|c|c|}
\hline \multirow[t]{2}{*}{ Sample } & \multirow[t]{2}{*}{ Determinant } & \multicolumn{2}{|c|}{$\begin{array}{l}\text { Pooled OLS } \\
\text { estimator }\end{array}$} & \multicolumn{2}{|c|}{$\begin{array}{c}\text { Pooled FGLS } \\
\text { estimator }\end{array}$} & \multicolumn{2}{|c|}{$\begin{array}{l}\text { Within or FE } \\
\text { estimator }\end{array}$} & \multicolumn{2}{|c|}{$\begin{array}{c}\text { Between or BE } \\
\text { estimator }^{\mathrm{d}}\end{array}$} & \multicolumn{2}{|c|}{$\begin{array}{c}\text { Random-effects or RE } \\
\text { estimator }\end{array}$} \\
\hline & & coef. & t stat. & coef. & t stat. & coef. & t stat. & coef. & t stat. & coef. & t stat. \\
\hline Developin & FIF & 0.2315298 & $(0.62)$ & 0.2600768 & $\left(1.88^{*}\right)$ & 0.3032635 & (1.61) & 0.1529891 & $(0.45)$ & 0.2901588 & (1.62) \\
\hline
\end{tabular}

FIF, fiscal freedom variable, coef., coefficients., t stat., t statistics; OLS, Ordinary Least Square; FGLS, Feasible Generalised Least Squares; FE, fixed effects; BE, between model; RE, random-effects.

a, $R^{2}=0.004 N=996$ F-test $\left(\right.$ Prob $>$ F) $=0.53$ Std. Err. $=0.3711015 ;{ }^{b}, N=979$ Std. Err. $=0.1381579$ Correlation $=\operatorname{ar}(1) ;{ }^{c}, N=996 R^{2}:($ wit. $=0.009$ bet. $=0.002$ ov. $=0.004)$ Std. Err. $=0.1884935$ sigma_u $=$ 37.50 sigma_e $=13.29 ;{ }^{\mathrm{d}}, N=996 R^{2}$ : (wit. $=0.009$ bet. $=0.002$ ov. $\left.=0.004\right)$ Std. Err. $=0.3428475 ;{ }^{e}, N=996 R^{2}:($ wit. $=0.009$ bet. $=0.002$ ov. $=0.004)$ Std. Err. $=0.1792181$ sigma_u $=37.29$ sigma_e $=13.28$.

$*$, Denotes significant at $10 \%$ level, $* *$, significant at $5 \%$ level, $* * *$, significant at $1 \%$ level.

TABLE 5: Variation of Corruption Perceptions Index depends on gross domestic product, by stage of development: All.

\begin{tabular}{|c|c|c|c|c|c|c|c|c|c|c|c|}
\hline \multirow[t]{2}{*}{ Sample } & \multirow[t]{2}{*}{ Determinant } & \multicolumn{2}{|c|}{$\begin{array}{l}\text { Pooled OLS } \\
\text { estimator }^{\mathrm{a}}\end{array}$} & \multicolumn{2}{|c|}{$\begin{array}{l}\text { Pooled FGLS } \\
\text { estimator }\end{array}$} & \multicolumn{2}{|c|}{$\begin{array}{l}\text { Within or FE } \\
\text { estimator }\end{array}$} & \multicolumn{2}{|c|}{$\begin{array}{l}\text { Between or BE } \\
\text { estimator }^{\mathrm{d}}\end{array}$} & \multicolumn{2}{|c|}{$\begin{array}{c}\text { Random-effects or RE } \\
\text { estimator }\end{array}$} \\
\hline & & coef. & t stat. & coef. & t stat. & coef. & t stat. & coef. & t stat. & coef. & t stat. \\
\hline All & GDP & -0.0017741 & $(-9.79 * * *)$ & -0.0001445 & $(-2.81 * * *)$ & 0.0002525 & $(2.53 * *)$ & -0.0018533 & $\left(-12.82^{* * *}\right)$ & -0.0003988 & $(-5.13 * * *)$ \\
\hline
\end{tabular}

OLS, Ordinary Least Square; FGLS, Feasible Generalised Least Squares; FE, fixed effects; BE, between model; RE, random-effects; coef., coefficients., t stat., t statistics; GDP, gross domestic product. ${ }^{\mathrm{a}}, R^{2}=0.449 \mathrm{~N}=1497 \mathrm{~F}$-test (Prob $\left.>\mathrm{F}\right)=0.000 \mathrm{Std}$. Err. $=0.00018 ;{ }^{\mathrm{b}}, N=1460 \mathrm{Std}$. Err. $=0.00005$ Corr $=\operatorname{ar}(1) ; \mathrm{c}, N=1497 R^{2}:$ (wit. $=0.005$ bet. $=0.483$ ov. $\left.=0.449\right)$ Std. Err. $=0.0001$ sigma_u $=52.05$ sigma_e $=11.98 ;{ }^{\mathrm{d}}, N=1497 R^{2}$ : (wit. $=0.005$ bet. $=0.483$ ov. $=0.449$ ) Std. Err. $=0.00014 ;{ }^{e}, N=1497 R^{2}$ : (wit. $=0.005$ bet. $=0.483$ ov. $\left.=0.449\right)$ Std. Err. $=0.00008$ sigma_u $=34.88$ sigma_e $=11.98$.

$*$, Denotes significant at $10 \%$ level, **, significant at $5 \%$ level, $* * *$, significant at $1 \%$ level. 
TABLE 6: Variation of Corruption Perceptions Index depends on gross domestic product, by stage of development: Developed.

\begin{tabular}{|c|c|c|c|c|c|c|c|c|c|c|c|}
\hline \multirow[t]{2}{*}{ Sample } & \multirow[t]{2}{*}{ Determinant } & \multicolumn{2}{|c|}{$\begin{array}{l}\text { Pooled OLS } \\
\text { estimator }^{\mathrm{a}}\end{array}$} & \multicolumn{2}{|c|}{$\begin{array}{l}\text { Pooled FGLS } \\
\text { estimator }\end{array}$} & \multicolumn{2}{|c|}{$\begin{array}{l}\text { Within or FE } \\
\text { estimator }\end{array}$} & \multicolumn{2}{|c|}{$\begin{array}{l}\text { Between or BE } \\
\text { estimator }{ }^{\mathrm{d}}\end{array}$} & \multicolumn{2}{|c|}{$\begin{array}{c}\text { Random-effects or RE } \\
\text { estimator }\end{array}$} \\
\hline & & coef. & t stat. & coef. & t stat. & coef. & t stat. & coef. & t stat. & coef. & t stat. \\
\hline Developed & GDP & -0.0008013 & $(-3.91 * * *)$ & -0.0010004 & $(-4.18 * * *)$ & 0.0000622 & $(0.96)$ & -0.0008487 & $(-4.27 * * *)$ & $3.69 \mathrm{e}-06$ & $(0.06)$ \\
\hline
\end{tabular}

OLS, Ordinary Least Square; FGLS, Feasible Generalised Least Squares; FE, fixed effects; BE, between model; RE, random-effects; coef., coefficients., t stat., t statistics; GDP, gross domestic product. a, $R^{2}=0.262 \mathrm{~N}=420$ F-test (Prob > F) $=0.000$ Std. Err. $=0.00021{ }^{\circ}{ }^{b}, N=420$ Std. Err. $=0.00024$ Corr $=\operatorname{ar}(1) ;{ }^{c}, N=420 R^{2}:($ wit. $=0.004$ bet. $=0.284$ ov. $=0.262)$ Std. Err. $=0.00006$ sigma u $=32.54$ sigma_e $=5.65 ;{ }^{\mathrm{d}}, N=420 R^{2}$ : (wit. $=0.004$ bet. $=0.284 \mathrm{ov} .=0.262$ ) Std. Err. $=0.0002 ;{ }^{\mathrm{e}}, N=420 R^{2}$ : (wit. $=0.004$ bet. $=0.284$ ov. $=0.262$ ) Std. Err. $=0.00006$ sigma_u $=27.19$ sigma_e $=5.65$. $*$, Denotes significant at $10 \%$ level, $* *$, significant at $5 \%$ level, $* * *$, significant at $1 \%$ level.

TABLE 7: Variation of Corruption Perceptions Index depends on gross domestic product, by stage of development: Developing.

\begin{tabular}{|c|c|c|c|c|c|c|c|c|c|c|c|}
\hline \multirow[t]{2}{*}{ Sample } & \multirow[t]{2}{*}{ Determinant } & \multicolumn{2}{|c|}{$\begin{array}{l}\text { Pooled OLS } \\
\text { estimator }^{\mathrm{a}}\end{array}$} & \multicolumn{2}{|c|}{$\begin{array}{c}\text { Pooled FGLS } \\
\text { estimator }^{b}\end{array}$} & \multicolumn{2}{|c|}{$\begin{array}{l}\text { Within or FE } \\
\text { estimator }\end{array}$} & \multicolumn{2}{|c|}{$\begin{array}{c}\text { Between or BE } \\
\text { estimator }^{\mathrm{d}}\end{array}$} & \multicolumn{2}{|c|}{$\begin{array}{c}\text { Random-effects or RE } \\
\text { estimator }^{c}\end{array}$} \\
\hline & & coef. & t stat. & coef. & t stat. & coef. & t stat. & coef. & t stat. & coef. & t stat. \\
\hline Developing & GDP & -0.0017611 & $(-5.07 * * *)$ & -0.0003812 & $(-2.56 * * *)$ & 0.0008721 & $(1.67 *)$ & -0.0019171 & $(-5.86 * * *)$ & -0.000034 & $(-0.11)$ \\
\hline
\end{tabular}

OLS, Ordinary Least Square; FGLS, Feasible Generalised Least Squares; FE, fixed effects; BE, between model; RE, random-effects; coef., coefficients., t stat., t statistics; GDP, gross domestic product. ${ }^{\mathrm{a}}, R^{2}=0.177 \mathrm{~N}=1076 \mathrm{~F}$-test (Prob $\left.>\mathrm{F}\right)=0.000 \mathrm{Std}$. Err. $=0.00035 ; \mathrm{b}, N=1076 \mathrm{Std}$. Err. $=0.00015$ Corr $=\operatorname{ar}(1) ; \mathrm{c}, N=1076 R^{2}:($ wit. $=0.015$ bet. $=0.211 \mathrm{ov} .=0.177)$ Std. Err. $=0.00052 \mathrm{sigma}$ _u $=43.1$ sigma_e $=13.63 ;{ }^{d}, N=1076 R^{2}:$ (wit. $=0.015$ bet. $=0.211$ ov. $=0.177$ ) Std. Err. $=0.00033 ;{ }^{\mathrm{e}}, N=1076 R^{2}:($ wit. $=0.015$ bet. $=0.211$ ov. $=0.177)$ Std. Err. $=0.0003$ sigma_u $=34.21$ sigma_e $=13.63$. $*$, Denotes significant at $10 \%$ level, $* *$, significant at $5 \%$ level, $* * *$, significant at $1 \%$ level.

TABLE 8: Variation of Corruption Perceptions Index depends on government effectiveness, by stage of development: All.

\begin{tabular}{|c|c|c|c|c|c|c|c|c|}
\hline \multirow[t]{2}{*}{ Sample } & \multirow[t]{2}{*}{ Determinant } & $\begin{array}{l}\text { Pooled OLS } \\
\text { estimator }^{\mathrm{a}}\end{array}$ & $\begin{array}{l}\text { Pooled FGLS } \\
\text { estimator }\end{array}$ & $\begin{array}{l}\text { Within or } \mathrm{FE} \\
\text { estimator }\end{array}$ & \multicolumn{2}{|c|}{$\begin{array}{l}\text { Between or BE } \\
\text { estimator }{ }^{\mathrm{d}}\end{array}$} & \multicolumn{2}{|c|}{$\begin{array}{c}\text { Random-effects or RE } \\
\text { estimator }^{\mathrm{e}}\end{array}$} \\
\hline & & t stat. & $\mathrm{t}$ stat. & $\mathrm{t}$ stat. & coef. & $\mathrm{t}$ stat. & coef. & t stat. \\
\hline
\end{tabular}

\begin{tabular}{|c|c|c|c|c|c|c|c|c|c|c|}
\hline All & GE & -46.0 & $(-45,29 * * *)$ & $-36.7>$ & $(-33$ & & $(-38)-1$ & -46 & & $(-39.48 * * *)$ \\
\hline
\end{tabular}

OLS, Ordinary Least Square; FGLS, Feasible Generalised Least Squares; FE, fixed effects; BE, between model; RE, random-effects; GE, government effectiveness, coef., coefficients., $t$ stat., $t$ statistics. a, $R^{2}=0.838 N=1530$ F-test $($ Prob $>$ F $)=0.000$ Std. Err. $=1.017 ;{ }^{b}, N=1485$ Std. Err. $=1.106$ Corr $=\operatorname{ar}(1) ;{ }^{c}, N=1530 R^{2}:($ wit. $=0.034$ bet. $=0.883$ ov. $=0.838)$ Std. Err. $=4.96$ sigma_u $=32.39$ sigma_e $=$ 11.87; ${ }^{\mathrm{d}}, N=1530 R^{2}$ : (wit. $=0.034$ bet. $=0.883$ ov. $=0.838$ ) Std. Err. $=1.27 ;{ }^{\mathrm{e}}, N=1530 R^{2}$ : (wit. $=0.034$ bet. $=0.883$ ov. $\left.=0.838\right)$ Std. Err. $=1.06$ sigma_u $=16.47$ sigma_e $=11.87$.

$*$, Denotes significant at $10 \%$ level, $* *$, significant at $5 \%$ level, $* * *$, significant at $1 \%$ level.

TABLE 9: Variation of Corruption Perceptions Index depends on government effectiveness, by stage of development: Developed.

\begin{tabular}{|c|c|c|c|c|c|c|c|c|c|c|c|}
\hline \multirow[t]{2}{*}{ Sample } & \multirow[t]{2}{*}{ Determinant } & \multicolumn{2}{|c|}{$\begin{array}{l}\text { Pooled OLS } \\
\text { estimator }^{\mathrm{a}}\end{array}$} & \multicolumn{2}{|c|}{$\begin{array}{l}\text { Pooled FGLS } \\
\text { estimator }\end{array}$} & \multicolumn{2}{|c|}{$\begin{array}{l}\text { Within or FE } \\
\text { estimator }\end{array}$} & \multicolumn{2}{|c|}{$\begin{array}{l}\text { Between or BE } \\
\text { estimator }\end{array}$} & \multicolumn{2}{|c|}{$\begin{array}{c}\text { Random-effects or } \mathrm{RE} \\
\text { estimator }\end{array}$} \\
\hline & & coef. & t stat. & coef. & t stat. & coef. & t stat. & coef. & t stat. & coef. & t stat. \\
\hline Developed & GE & -39.02185 & $(-9.91 * * *)$ & -34.88357 & $(-8.22 * * *)$ & -10.53626 & $(-1.90 * *)$ & -39.15228 & $(-15.94 * * *)$ & -26.55898 & $(-5.30 * * *)$ \\
\hline
\end{tabular}

OLS, Ordinary Least Square; FGLS, Feasible Generalised Least Squares; FE, fixed effects; BE, between model; RE, random-effects; GE, government effectiveness, coef., coefficients., $t$ stat., $t$ statistics.

a $R^{2}=0.833 N=429$ F-test $($ Prob $>$ F $)=0.000$ Std. Err. $=3.938 ;{ }^{b}, N=429$ Std. Err. $=4.243$ Corr $=\operatorname{ar}(1) ;{ }^{c}, N=429 R^{2}:($ wit. $=0.037$ bet. $=0.843$ ov. $=0.825)$ Std. Err. $=5.547$ sigma_u $=24.56$ sigma_e $=$ $5.50 ;{ }^{\mathrm{d}}, N=429 R^{2}$ : (wit. $=0.037$ bet. $=0.843$ ov. $=0.825$ ) Std. Err. $=2.456 ;{ }^{\mathrm{e}}, N=429 R^{2}$ : (wit. $=0.037$ bet. $=0.843$ ov. $=0.825$ ) Std. Err. $=7.40$ sigma_u $=12.45$ sigma_e $=5.50$.

$*$, Denotes significant at $10 \%$ level, $* *$, significant at $5 \%$ level, $* * *$, significant at $1 \%$ level.

TABLE 10: Variation of Corruption Perceptions Index depends on government effectiveness, by stage of development: Developed.

\begin{tabular}{|c|c|c|c|c|c|c|c|c|c|c|c|}
\hline \multirow[t]{2}{*}{ Sample } & \multirow[t]{2}{*}{ Determinant } & \multicolumn{2}{|c|}{$\begin{array}{l}\text { Pooled OLS } \\
\text { estimator }^{\mathrm{a}}\end{array}$} & \multicolumn{2}{|c|}{$\begin{array}{l}\text { Pooled FGLS } \\
\text { estimator }^{b}\end{array}$} & \multicolumn{2}{|c|}{$\begin{array}{l}\text { Within or FE } \\
\text { estimator }\end{array}$} & \multicolumn{2}{|c|}{$\begin{array}{c}\text { Between or BE } \\
\text { estimator }^{\mathrm{d}}\end{array}$} & \multicolumn{2}{|c|}{$\begin{array}{c}\text { Random-effects or RE } \\
\text { estimator }^{\mathrm{e}}\end{array}$} \\
\hline & & coef. & t stat. & coef. & t stat. & coef. & t stat. & coef. & t stat. & coef. & t stat. \\
\hline Developing & GE & -51.12601 & $(-24.66 * * *)$ & -34.53489 & $(-15.95 * * *)$ & -21.52508 & $(-3.53 * * *)$ & -52.03406 & $(-22.83 * * *)$ & -43.03022 & $(-21.59 * * *)$ \\
\hline
\end{tabular}

OLS, Ordinary Least Square; FGLS, Feasible Generalised Least Squares; FE, fixed effects; BE, between model; RE, random-effects; GE, government effectiveness, coef., coefficients., $t$ stat., $t$ statistics. a, $R^{2}=0.177 \mathrm{~N}=1100 \mathrm{~F}$-test $($ Prob $>\mathrm{F})=0.000 \mathrm{Std}$. Err. $=2.073 ;{ }^{\mathrm{b}}, N=1055 \mathrm{Std}$. Err. $=2.165 \mathrm{Corr}=\operatorname{ar}(1) ;{ }^{\mathrm{c}}, N=1100 R^{2}:($ wit. $=0.037$ bet. $=0.8 \mathrm{ov} .=0.71)$ Std. Err. $=6.09 \mathrm{sigma} \_\mathrm{u}=27.24 \mathrm{sigma} \_$e $=13.57$; d, $N=1100 R^{2}$ : (wit. $=0.037$ bet. $=0.8$ ov. $\left.=0.71\right)$ Std. Err. $=1.90 ;{ }^{e}, N=1100 R^{2}$ : (wit. $=0.037$ bet. $=0.8$ ov. $\left.=0.71\right)$ Std. Err. $=1.99$ sigma_u $=17.03$ sigma_e $=13.57$.

$*$, Denotes significant at $10 \%$ level, $* *$, significant at $5 \%$ level, $* * *$, significant at $1 \%$ level.

concerning the random-effects of countries. The same problem occurs when Hypothesis 2 is tested for developing countries. Estimators (3) and (5) are based on within variation and are small in relation to between variations. Noteworthy is that this hypothesis is validated in all three cases through the use of models (1), (2) and (4), models based on between variation. The between variation and errors of correlation are relevant. It is worth noting that reduction in corruption because of increase in income is higher in developing countries than in developed ones. Similar findings belong to Treisman (2000) and Paldam (2001, 2002), who found that eradication of poverty could reduce corruption (see the value of coefficients variable GDP for each model). Overall, the findings of the present study are in line with theory showing that low-income countries face high levels of corruption (De Rosa et al. 2010; Gundlach and Paldam 2009; Husted 1999; Paldam 2001, 2002; Treisman 2000).
Thirdly, Hypothesis 3 examined the influence of institutional quality on the level of corruption. The results are presented in Tables 8-10.

The results of testing Hypothesis 3 in relation to the development stage are homogeneous. The coefficients of GE determinant in all five models have 5\% significance level. The negative sign of GE coefficient confirms our Hypothesis 3. Our findings are also supported by the studies of Kirchler (2007), Torgler and Schneider (2009) and Park and Blenkinsopp (2011) who reported that high institutional quality involves few attempts to circumvent the law, and thus corruption decreases. Moreover, a recent study conducted by Forson et al. (2016) over 22 countries in sub-Saharan Africa from 1996 to 2013 found that GE and regulatory quality bred substantial corruption. They agreed about sources of corruption from the perspective 
of institutional ineffectiveness. Moreover, Kirchler (2007), Torgler and Schneider (2009) and Park and Blenkinsopp (2011) reported that high institutional quality involves few attempts to circumvent the law, and thus corruption decreases.

It should be noted that the influence of institutional quality on corruption is much greater in developing countries than in developed countries. Excessive bureaucracy, lack of transparency and ambiguous legislation highly affect poor people, who will succumb to the dictates of corrupt officials in order to achieve some immediate benefits.

Finally, Hypothesis 4 and Research question 4 involve analysis of the variation of corruption caused by simultaneous influence of fiscal freedom, institutional quality and income of a country. The results are listed in Tables 11-13.

Because the factors GE and GDP are not independent and are very much correlated (correlation coefficient is 0.76 ), only the variables FIF and GE were considered as determinants in the model of corruption. The results show that for all the countries, the impact of governance efficiency is consistent, and the sign of GE coefficient is in line with Hypothesis 4 . The influence of fiscal freedom is statistically significant in models (2), (3) and (5). This fact is because of the errors in correlation and the change of tax freedom during the 9 years. It must be emphasised that the coefficient of FIF is positive and unexpected. This means that increasing fiscal freedom leads to more corruption, which also contradicts the expectations.

However, the running tests conducted separately on developed and developing countries lead to some interesting findings. Thus, for developed countries, the hypothesis is valid in models (1) and (4), and the sign of the variable FIF is, for the first time, in line with our expectations (e.g. negative). It means that high fiscal freedom (low fiscal pressure) reduces corruption in developed economies when controlling for governance effectiveness. In developed countries, the high level of institutions leads to strong control by the state, and thus low fiscal freedom (high fiscal pressure) increases corruption. Thus, here the theory is supported. Because model (2) is not convergent, it is not considered in the present analysis.

For developing countries, the influences of FIF and GE are significant, but the coefficient of FIF is positive, again, contrary to our expectations, but in line with the previous results when the variation of CPI was analysed only under the variation of FIF. For these countries, whether it controls or not for governance effectiveness, the sign of the FIF determinant remains positive, meaning that a higher level of fiscal freedom (together with low fiscal pressure) leads to a higher level of corruption. In developing countries, the efficiency of institutions is lower in comparison to developed countries. In these countries, the government institutions are weak, and do not succeed in controlling corruption. Thus,

TABLE 11: Variation of corruption depends on fiscal freedom variable and government effectiveness, by level of development: All.

\begin{tabular}{|c|c|c|c|c|c|c|c|c|c|c|c|}
\hline \multirow[t]{2}{*}{ Sample } & \multirow[t]{2}{*}{ Determinant } & \multicolumn{2}{|c|}{$\begin{array}{l}\text { Pooled OLS } \\
\text { estimator }\end{array}$} & \multicolumn{2}{|c|}{$\begin{array}{l}\text { Pooled FGLS } \\
\text { estimator }\end{array}$} & \multicolumn{2}{|c|}{$\begin{array}{l}\text { Within or FE } \\
\text { estimator }^{c}\end{array}$} & \multicolumn{2}{|c|}{$\begin{array}{l}\text { Between or BE } \\
\text { estimator }\end{array}$} & \multicolumn{2}{|c|}{$\begin{array}{l}\text { Random-effects or RE } \\
\text { estimator }\end{array}$} \\
\hline & & coef. & t stat. & coef. & t stat. & coef. & t stat. & coef. & t stat. & coef. & t stat. \\
\hline \multirow[t]{2}{*}{ All } & FIF & 0.0162808 & $(0.15)$ & 0.2633563 & $(2.82 * * *)$ & 0.2839865 & $(1.83 *)$ & 0.0067072 & $(0.06)$ & 0.2508473 & $\left(2.30^{* *}\right)$ \\
\hline & GE & -45.48843 & $(-39.28 * * *)$ & -34.98761 & $(-27.47 * * *)$ & -18.8051 & $(-3.85 * * *)$ & -45.60882 & $(-32.13 * * *)$ & -39.71134 & $(-32.05 * * *)$ \\
\hline
\end{tabular}

OLS, Ordinary Least Square; FGLS, Feasible Generalised Least Squares; FE, fixed effects; BE, between model; RE, random-effects; FIF, Fiscal freedom variable; GE, government effectiveness, coef., coefficients., t stat., $\mathrm{t}$ statistics.

${ }^{\mathrm{a}}, R^{2}=0.832 \mathrm{~N}=1417$ F-test $($ Prob $>\mathrm{F})=0.000 ;{ }^{\mathrm{b}}, N=1400 \mathrm{Corr}=\operatorname{ar}(1) ;{ }^{\mathrm{c}}, N=1417 R^{2}:$ ( wit. $=0.042$ bet. $=0.84$ ov. $\left.=0.81\right)$ sigma_u $=30.80$ sigma_e $=11.40 ;{ }^{\mathrm{d}}, N=1417 R^{2}:($ wit. $=0.033$ bet. $=0.87$ ov. $=0.83) ; \mathrm{e}, N=1417 R^{2}$ : (wit. $=0.038$ bet. $=0.86$ ov. $\left.=0.83\right)$ sigma_u $=16.95$ sigma_e $=11.34$.

$*$, Denotes significant at $10 \%$ level; **, significant at $5 \%$ level; ***, significant at $1 \%$ level; $t$ statistics $/ 2$-statistic in parentheses.

TABLE 12: Variation of corruption depends on fiscal freedom variable and government effectiveness, by level of development: Developed.

\begin{tabular}{|c|c|c|c|c|c|c|c|c|c|c|c|}
\hline \multirow[t]{2}{*}{ Sample } & \multirow[t]{2}{*}{ Determinant } & \multicolumn{2}{|c|}{$\begin{array}{l}\text { Pooled OLS } \\
\text { estimator }\end{array}$} & \multicolumn{2}{|c|}{$\begin{array}{l}\text { Pooled FGLS } \\
\text { estimator }\end{array}$} & \multicolumn{2}{|c|}{$\begin{array}{l}\text { Within or FE } \\
\text { estimatorc }\end{array}$} & \multicolumn{2}{|c|}{$\begin{array}{l}\text { Between or BE } \\
\text { estimator }{ }^{d}\end{array}$} & \multicolumn{2}{|c|}{$\begin{array}{c}\text { Random-effects or RE } \\
\text { estimator }\end{array}$} \\
\hline & & coef. & t stat. & coef. & t stat. & coef. & t stat. & coef. & t stat. & coef. & t stat. \\
\hline \multirow[t]{2}{*}{ Developed } & FIF & -0.2249265 & $\left(-2.01^{* *}\right)$ & - & - & -0.059837 & $(-0.25)$ & -0.2606813 & $(-2.14 * *)$ & 0.0140044 & $(0.10)$ \\
\hline & GE & -42.08028 & $(-10.37 * * *)$ & - & - & -12.57569 & $(-2.26 * *)$ & -42.79719 & $(-15.67 * * *)$ & -28.63641 & $(-5.32 * * *)$ \\
\hline
\end{tabular}

OLS, Ordinary Least Square; FGLS, Feasible Generalised Least Squares; FE, fixed effects; BE, between model; RE, random-effects; FIF, fiscal freedom variable; GE, government effectiveness, coef. coefficients., t stat., t statistics.

a, $R^{2}=0.846 \mathrm{~N}=420$ F-test $\left(\right.$ Prob $>$ F) $=0.000 ;{ }^{b}, 0.3992288 ;{ }^{c}, N=420 R^{2}:($ wit. $=0.052$ bet. $=0.86$ ov. $=0.85)$ sigma_u $=23.87$ sigma_e $=5.44 ;{ }^{d}, N=420 R^{2}:($ wit. $=0.052$ bet. $=0.86$ ov. $=0.85)$;

$e^{\prime}, N=420 R^{2}$ : (wit. $=0.052$ bet. $=0.86$ ov. $\left.=0.85\right)$ sigma_u $=11.72$ sigma_e $=5.44$.

$*$, Denotes significant at $10 \%$ level, $* *$, significant at $5 \%$ level, $* * *$, significant at $1 \%$ level.

TABLE 13: Variation of corruption depends on fiscal freedom variable and government effectiveness, by level of development: Developing.

\begin{tabular}{|c|c|c|c|c|c|c|c|c|c|c|c|}
\hline \multirow[t]{2}{*}{ Sample } & \multirow[t]{2}{*}{ Determinant } & \multicolumn{2}{|c|}{$\begin{array}{l}\text { Pooled OLS } \\
\text { estimator }^{\mathrm{a}}\end{array}$} & \multicolumn{2}{|c|}{$\begin{array}{l}\text { Pooled FGLS } \\
\text { estimator }\end{array}$} & \multicolumn{2}{|c|}{$\begin{array}{l}\text { Within or FE } \\
\text { estimatorc }\end{array}$} & \multicolumn{2}{|c|}{$\begin{array}{l}\text { Between or BE } \\
\text { estimator }^{\mathrm{d}}\end{array}$} & \multicolumn{2}{|c|}{$\begin{array}{c}\text { Random-effects or RE } \\
\text { estimator }\end{array}$} \\
\hline & & coef. & t stat. & coef. & t stat. & coef. & t stat. & coef. & t stat. & coef. & t stat. \\
\hline \multirow[t]{2}{*}{ Developing } & FIF & 0.3992288 & $\left(2.63^{* *}\right)$ & 0.3521478 & $(2.89 * * *)$ & 0.3505268 & $(1.99 * *)$ & 0.4297716 & $(2.60 * *)$ & 0.3898608 & $(2.89 * * *)$ \\
\hline & GE & -51.42317 & $(-21.73 * * *)$ & -34.13502 & $(-14.50 * * *)$ & -21.04365 & $(-3.50 * * *)$ & -52.14321 & $\left(-20.12^{* * *}\right)$ & -41.7466 & $(-18.51 * * *)$ \\
\hline
\end{tabular}

FIF, fiscal freedom variable; $G E$, government effectiveness, coef., coefficients., $\mathrm{t}$ stat., $\mathrm{t}$ statistics.

a, $R^{2}=0.69 N=996$ F-test (Prob $>$ F) $=0.000 ;{ }^{\text {b }}, N=979 \mathrm{Corr}=\operatorname{ar}(1) ;{ }^{\mathrm{c}}, N=996 R^{2}$ : (wit. $=0.045$ bet. $=0.76$ ov. $\left.=0.68\right)$ sigma u $=26.58$ sigma e $=13.04 ;{ }^{\text {d }}, N=996 R^{2}:$ (wit. $=0.043$ bet. $=0.77$ ov. $=0.69$ ); $e^{e}, N=996 R^{2}$ : (wit. $=0.043$ bet. $=0.77$ ov. $=0.69$ ) sigma_u $=17.39$ sigma_e $=13.04$.

$*$, Denotes significant at $10 \%$ level, $* *$, significant at $5 \%$ level, $* * *$, significant at $1 \%$ level. 
higher fiscal freedom (meaning lower fiscal pressure) leads to a higher level of corruption under weak-quality institutions.

One can conclude that, for the first time in our analysis, the influence of fiscal freedom on corruption follows expectations when the developed countries are surveyed and this relation is controlled by institutional quality. Thus, in well-developed institutions, high fiscal freedom (meaning low fiscal pressure) leads to a lower level of corruption, which is in line with expectations. For developing countries, higher fiscal freedom enhances corruption, because some regulations are effective in developed countries when GE is high but do not function in developing countries under weak levels of institutional quality.

Our mixed findings which resulted from testing Hypothesis 4 show some similarity with those obtained by several authors (Carden \& Verdon 2010; Graeff \& Mehlkop 2003; Kumar 2011). Firstly, they multi-dimensionally analysed the relationship between corruption and fiscal freedom. Secondly, they also found that the relationship between economic freedom and corruption varies according to the level of development of a country. More precisely, they stated that some types of regulations increase or decrease corruption, depending on whether countries are rich or poor (Graeff \& Mehlkop 2003). In addition we have empirical evidence of the important role of quality institutions which need to prevail in order to achieve effective anti-corruption policies.

\section{Conclusion}

The problem of corruption and its explanatory factors are widely debated in the literature. Acknowledging the causes of corruption on the part of policy-makers could open up the proper channels for fighting against it. The present study investigates whether higher fiscal burden may create opportunities for bribing officials, thus enhancing the level of corruption. Some control variables, such as richness and institutional quality were also used. A panel analysis on a large sample of 185 countries over the period 2005-2014 was used.

A first and overall result was obtained after analysing the influence of fiscal burden on corruption and without considering other determinants. Thus, we found a negative influence of fiscal burden on the level of corruption, which contradicts expectations. However, similar findings have also been obtained by other researchers, such as Dreher and Siemers $(2005,2009)$, Dreher and Schneider (2010) and McGee $(2008,2012)$.

The second result, also being our main contribution to previous work, consisted in finding differentiated results when the influence of fiscal burden on the level of corruption is controlled by income and institutional quality. In this respect, we found that, under high-quality institutions from developed countries, higher fiscal pressure leads to a higher level of corruption, which is in line with expectations. In the case of developing countries, the control of low-level institutional quality determines a strong and negative influence of fiscal pressure on the level of corruption. Thus, in developing countries, the influence of low-level institutional quality enhances the negative role of fiscal pressure on corruption. Here, low fiscal pressure increases corruption, because it is rather a matter of low governance efficiency under which people may easily circumvent the law. It can be concluded that the relationship between corruption and fiscal burden needs to be multi-dimensionally analysed, with income and the institution quality variable being a priority.

The third result consists in finding a negative influence of people's wealth and institutional quality on the level of corruption. This may explain why high-income countries with high institutional quality face low levels of corruption. These results are supported by a large strand of literature referring to the influence of wealth on the level of corruption (De Rosa et al. 2010; Gundlach \& Paldam 2009; Husted 1999; Paldam 2001, 2002; Treisman 2000 ) or the influence of institutional quality on the level of corruption (Forson et al. 2016; Kirchler 2007; Park \& Blenkinsopp 2011; Torgler \& Schneider 2009).

Our findings suggest that certain fiscal policies may work in some countries, but not in others, and may explain the legal efficiency of various anti-corruption policies which occur, especially in low-income countries. Thus, the present research may have important implications for governments and policy-makers in adopting the best decisions in the fight against corruption. They need to acknowledge the necessity to adopt differentiated tax policies, depending on the level of the country's development under the various levels of institutional quality (bureaucracy, quality of public services, ability to collect taxes, produce and implement good policies and deliver public goods). Low fiscal burden may reduce corruption in developed countries, and enhance it in developing countries under various levels of governance efficiency. Thus, governments and policy-makers need to acknowledge that the anti-corruption fight requires not only the right fiscal policies, but also the best way of implementing these policies, recognising the role of quality institutions which should prevail in any country.

The limitation of this research consists in not using some behavioural patterns of corruption, such as culture and religion. Therefore, in order to reduce the limitations and substantiate the present findings, future work should be analysed multi-dimensionally, through the use of such behaviour variables.

\section{Acknowledgements Competing interests}

No potential conflict of interest was reported by the authors.

\section{Authors' contributions}

M.V.A. is responsible for the topic of research, performing the statistical methodology, compilation of the statistical and economical interpretation of the results, language and the 
general overview. S.N.B. is responsible for making the literature review, assessing the hypotheses and economical interpretation of results, and assessing the economic conclusions. A.M.A. is responsible for the compilation of the statistical and economical interpretation of the results and assessing the economic conclusions.

\section{References}

Carden, A. \& Verdon, L., 2010, 'When is corruption a substitute for economic freedom?', The Law and Development Review 3(1). https://doi.org/10.2202/1943 3867.1050

Conseil de l' Europe, 1996, Programme d'action la corruption adoptế par le Comitế des Ministres, Strasbourg, viewed 01 November 2017, from https://rm.coe. int/16806ccfb5

De Rosa, D., Gooroochurn, N. \& Gorg, H., 2010, Corruption and productivity: Firm-level evidence from the BEEPS survey, Policy Research Working Paper no. WPS 5348 , World Bank, viewed March 2017 from https://openknowledge.worldbank.org/ handle/10986/4000

Dreher, A., Kotsogiannis, C. \& McCorriston, S., 2009, 'How do institutions affect corruption and the shadow economy?', International Tax and Public Finance 16, 773-796. https://doi.org/10.1007/s10797-008-9089-5

Dreher, A. \& Schneider, F., 2010, 'Corruption and the shadow economy. An empirical analysis', Public Choice 144(1), 215-238. https://doi.org/10.1007/s11127-0099513-0

Dreher, A. \& Siemers, L.-H.R., 2005, The intriguing nexus between corruption and capital account restrictions, ETH Zurich Research Collection, no. 113, viewed March 2017 from http://econwpa.repec.org/eps/dev/papers/0306/0306004.pdf

Dreher, A. \& Siemers, L.-H.R., 2009, 'The nexus between corruption and capital account restrictions', Public Choice 140, 245-265. https://doi.org/10.1007/ s11127-009-9423-1

Fjeldstad, O.H., 1996, Tax evasion and corruption in local governments in Tanzania: Alternative economic approaches, Working Paper 14, Chr. Michelsen Institute Development Studies and Human Rights, Bergen, Norway.

Fjeldstad, O.H., 2003, 'Fighting fiscal corruption: Lessons from the Tanzania revenue authority', Public Administration and Development 23, 165-175. https://doi. org/10.1002/pad.278

Forson, J.A., Baah-Ennumh, T.Y., Buracom, P., Guojin, C. \& Peng, Z., 2016, 'Causes of corruption: Evidence from sub-Saharan Africa', South African Journal of Economic and Management Sciences 19(4), 562-578. https://doi.org/10.4102/sajems. v19i4.1530

Fritzen, S.A., Serritzlew, S. \& Svendsen, G.T., 2014, 'Corruption, trust and their public sector consequences: Introduction to the special edition', Journal of Comparative sector consequences: Introduction to the special edition', Journal of Comparative
Policy Analysis: Research and Practice 16(2), 117-120. https://doi.org/10.1080/1 Policy Analysis: Resear

Goel, R.G. \& Ram, R., 2013, 'Economic uncertainty and corruption: Evidence from a large cross-country data set', Applied Economics 45(24), 3462-3468. https://doi. large cross-country data set', Applied
org/10.1080/00036846.2012.714073

Graeff, P. \& Mehlkop, G., 2003, 'The impact of economic freedom on corruption: Different patterns for rich and poor countries', European Journal of Political Economy 19, 605-620. https://doi.org/10.1016/S0176-2680(03)00015-6

Gundlach, E. \& Paldam, M., 2009, 'The transition of corruption: From poverty to honesty', Economic Letters 103, 146-148. https://doi.org/10.1016/j.econlet. 2009.03.002

Heritage Foundation, 2017, Index of economic freedom, Washington, DC, viewed February 2017, from http://www.heritage.org/index/fiscal-freedom/
Huang, C.-J., 2016, 'Is corruption bad for economic growth? Evidence from Asia-Pacific countries', The North American Journal of Economics and Finance 35, 247-256. https://doi.org/10.1016/j.najef.2015.10.013

Husted, B.W., 1999, 'Wealth, culture, and corruption', Journal of International Business Studies 30(2), 339-359. https://doi.org/10.1057/palgrave.jibs.8490073

Jiang, T. \& Nie, H., 2014, 'The stained China miracle: Corruption, regulation, and firm performance', Economics Letters 123, 366-369. https://doi.org/10.1016/j. econlet.2014.03.026

Kaufman, D., 2010, Can corruption adversely affect public finances in industrialized countries? The Brookings Institution, Washington, DC, viewed March 2017, from https://www.brookings.edu/opinions/can-corruption-adversely-affect-publicfinances-in-industrialized-countries/

Kirchler, E., 2007, The economic psychology of tax behavior, Cambridge University Press, Cambridge, England.

Kumar, A., 2011, Interplay between corruption and economic freedom, CCS Working Paper, No. 254, Summer Research Internship Programme 2011, Centre for Civil Society, New Delhi.

Lambsdorff, J.G., 2003, 'How corruption affects productivity', Kyklos 56(4), 457-474. https://doi.org/10.1046/j.0023-5962.2003.00233.x

Mauro, P., 1995, 'Corruption and growth', The Quarterly Journal of Economics 110(3), 681-712. https://doi.org/10.2307/2946696

McGee, R.W., 2008, Taxation and public finance in transition and developing economies, Springer, North Miami, FL.

McGee, R.W., 2012, The ethics of tax evasion: Perspectives in theory and practice, Springer, North Miami, FL.

Park, H. \& Blenkinsopp, J., 2011, 'The roles of transparency and trust in the relationship between corruption and citizen satisfaction', International Review of Administrative Sciences 77(2), 254-274. https://doi.org/10.1177/00208523113 99230

Paldam, M., 2001, 'Corruption and religion. Adding to the economic model', Kyklos 54, 383-414. https://doi.org/10.1111/1467-6435.00160

Paldam, M., 2002, 'The big pattern of corruption: Economics, culture and the see saw dynamics', European Journal of Political Economy 18, 215-240. https://doi. org/10.1016/S0176-2680(02)00078-2

Treisman, D., 2000, 'The causes of corruption: A cross-national study', Journal of Public Economics 76, 399-457. https://doi.org/10.1016/S0047-2727(99) 00092-4

Schneider, F., Buehn, A. \& Montenegro, C.E., 2010, 'New estimates for the shadow economies all over the world', International Economic Journal 24(4), 443-461. https://doi.org/10.1080/10168737.2010.525974

Torgler, B. \& Schneider, F., 2009, 'The impact of tax morale and institutional quality on the shadow economy', Journal of Economic Psychology 30(2), 228-245. https:// doi.org/10.1016/j.joep.2008.08.004

Transparency International, 2015, Corruption perceptions index, viewed March 2017, from www.transparency.org/research/cpi

Virta, H., 2007, Corruption and shadow economy: Differences in the relationship between countries, Discussion Papers, Helsinki Center of Economic Research, University of Helsinki, Helsinki, Finland, pp. 1-26.

World Bank, 1997, Helping countries combat corruption: The role of the World Bank, World Bank Group, Washington, DC.

World Bank, 2015, World Bank report on 'Country and Lending Groups 2015', viewed February 2016, from https://datahelpdesk.worldbank.org/knowledgebase/ articles/906519-world-bank-country-and-lending-groups

World Bank, 2016a, Indicators, viewed February 2016, from https://data.worldbank. org/indicator.

World Bank, 2016b, Worldwide governance indicators, viewed September 2016, from http://info.worldbank.org/governance/wgi/\#home 